\title{
ФУНКЦИОНАЛЬНО ЗАМЕЩЕННЫЕ КАРБОЦИАНИНЫ КАК ОСНОВА ДЛЯ СИНТЕТИЧЕСКОГО ДИЗАЙНА ФЛУОРЕСЦЕНТНЫХ МЕТОК
}

\author{
И.А. Дорошенко, К.Г. Аминулла, Т.А. Подругина \\ Химический факультет, Московский государственный университет \\ им. М.В.Ломоносова, 119991, Российская Федерация, \\ Москва, ГСП-1, Ленинские горы, д. 1, стр. 3.
}

DOI: 10.19163/MedChemRussia2021-2021-343

E-mail: doroshenkoiran@gmail.com

Для исследований в области медицины и биологии, требующих визуализации процессов, удобным инструментом являются карбоцианины. Возможность разнообразной функционализации красителей расширяет границы их применения. Именно поэтому данные соединения являются перспективными с точки зрения их использования в различных направлениях: в качестве флуоресцентных биомаркеров, флуоресцентных зондов и как основа для создания конъюгатов «drug-delivery» [1-3].

В настоящей работе осуществлен синтез функционально замещенных карбоцианинов, модифицированных по мезо-положению или в линкере при кватернизированном атоме азота, с целью создания основы для конъюгатов. На конформационно закрепленных трикарбоцианинах I выявлена зависимость возможности проникновения флуорофора в клетку от его структуры. На полиметиновых красителях II показано, что комбинация в молекуле флуорофора алкильных, карбоксиалкильных и алкилсульфонатных заместителей позволяет обеспечить необходимый баланс гидрофильности и липофильности для использования их нековалентных конъюгатов во флуориметрических методах, основанных на агрегации. Кроме того, установлено, что при разработке новых методов биоимиджинга карбоцианины структурных типов I и II, содержащие азидный или алкинильный фрагмент, могут успешно выступать как основа для клик-процессов при создании флуоресцентно-меченых ковалентных конъюгатов с антибиотиками.

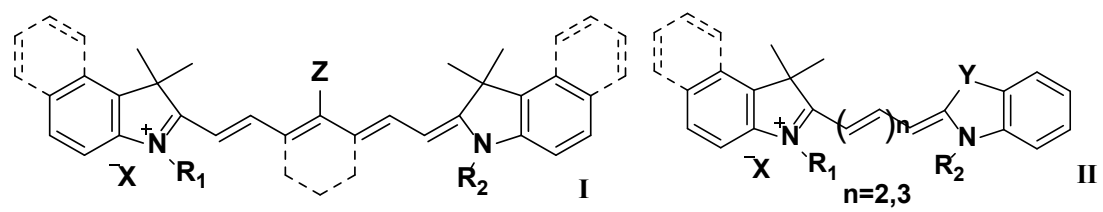

\section{Литература}

[1] S.A. Zakharenkova, E.A. Katkova, I.A. Doroshenko et al., Spectrochimica Acta Part A: Molecular and Biomolecular Spectroscopy, 2021, 247, 119109

[2] T.A. Podrugina, A.S. Pavlova, I.A. Doroshenko, V.A. Kuz'min, A.A. Kostyukov, and A.A. Shtil., Russ. Chem. Bull., Int. Ed., 2018, 67, 806-814

[3] P.J. Choi, T.I.-H. Park, E. Cooper, M. Dragunow,W.A. Denny, and J. Jose, Bioconjugate Chem., 2020, 31, 1724-1739 